ciable amount of additional apparatus. Not only does the cost of the oscillator go up, but the size also increases, and for many of the high-frequency applications, space is at a premium.

Practically all the circuits used for quartz crystal oscillators require that the reactance of the crystal be positive at the operating point. While harmonics of the fundmmental crystal frequency may be used with this type of circuit, therefore, only those giving a positive reactance are possible. Oscillators for a large part of the ultra-high-frequency range have thus been forced to employ harmonic generators, since the 5th harmonic of the thinnest usable crystal is only about $50 \mathrm{mc}$. This situation has now been ehanged by a circuit developed in these Laboratories and described in tho article, which permits crystal harmonies at least as high as the 23rd to be used for direct control of an oscillator circuit. Oscillators have been built for frequencies as high as $150 \mathrm{mc}$., using crystals with fundamental frequencios below $10 \mathrm{mc}$.

\section{SINHALA WEAPONS AND ARMOUR}

THE Journal of the Ceylon Branch of the Royal Asiatic Society for December 1942 contains an article by P. E. P. Deraniyagala on "Sinhala Weapons and Armor". The work of the Sinhalese armourers seems to have elicited great praise from Europeans of the seventeenth century, but one may legitimately doubt whether tempering swords in blood or milk made them any better as weapons, unless it were that they gave greater confidence. The Sinhalese court went in, apparently, for gladiatorial shows; fencing was taught, and foils (or singlesticks) were used in mock combat. The weapons illustrated include the boomerang, both of horn and of wood, and it is worth noting that the Koli name for it is katariya: very suggestive of the Latin name for itcateia. The prevalence of the leaf-shaped sword is striking. It is interesting to find in use the feathered javelin, if one can so describe it when the 'feather' was made of metal. Possibly the flat metal vanes were derived from vanes of pandanus leaf such as are used both for crossbow bolts and for javelins in the Assam hills.

A javelin feathered like an arrow appears in the hand of a god or hero in one of 'Titian's paintings, and Barbosa depicted a similar weapon in the hand of the King of Cochin riding on his elephant; some Eskimo harpoons are so constructed, but the type is a rare one. The author's description of a Sinhalese blowgun is tantalizing. Since he describes it as a wooden tube, it is presumably bored from wood in a single piece. Nlowguns of this kind are rarely so long as 80 in. except in Borneo. The tube is tapered, and we are told that "the poisoned dart was fixed with a lump of clay" at the nozzle and propelled by blowing up the tube from the other end, which sounds highly improbable, not to say inefficiont. A detailed account of these blowguns, their use and manufacture, of the darts, and of the poison used is much to be desired, as well as some account of the toy blowguns which we are told are still in use. Some of the other descriptions also leave much to be desired. The illustrations are good, but the author is probably wrong in describing Plate I, $b$, as representing wrestlers; the lefthand figure appears to be female and the other to be seated. In general, however, the article contains a useful and well-illustrated account of antiquated Sinhalese weapons.

\section{FORTHCOMING EVENTS}

\author{
Saturday, September 25
}

British Pgychologicat Society (at Tavistock House, Tavistock Square, London, W.C.1), at 2.30 p.m.- "Education of the Adolescent".

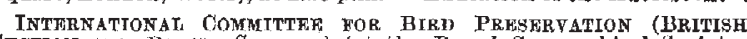
SECTION AND POLXSH SECHION) (at the Royal Geographical Society, Kensington Gore, London, S.W.7), at 2.30 p.m.-Dr. Jul. Borucki : "British Featherland" (colour flm).

\section{Tuesday, September 28}

BRITISH SOCIETY FOR INTERNATIONAL BIBIIOGRAPHY (at the Science Museum, Exhibition Road, South Kensington, London, S.W.7), at 4.30 p.m.-Prof. A. F. C. Pollard: "A Proposed Institute of Information".

ShefField Metallukgioal Association and SHeFhield SoOLety OF ENGINEERS AND METALLURGISTS (at the Royal Victoria Station Hotel, Sheffield), at 6.0 p.m.-Sir Lawrenee Bragg, F.R.S.: "The Strength of Metals".

\section{Wednesday, September 29}

Manchester Matalitrateat Society, The Imgtitute of Matatis and THE IRON AND STEFi INSTTTOTE (at the Engineer's Club Albert Square, Manchester), at 6.30 p.m.-Dr. W. H. Taylor: "Lattice Structures in Relation to Physical Propertics of Metals".

\section{Friday, October 1}

Association of APPLIFD BIOLOGISTs (at the Imperial College of Science and Technology, South Kensington, London, S.W.7), at 11 a.m. Symposing

Saturday, October 2

Assooration of SOIEn'irio Workers (at Essex Hall, Lissex Street Strand, London, W.C.2), at 2.30 p.m. Conference on "Problems of Freed Europe-The Challenge to the Medical Sciences". Problems of the Occupied Territories: Belgium (Dr. A. Marteau); Czecho(Prof. S. A. Sarkisov); Present Plans for Relief (Prof. J. R. Marrack). Grologists' Association (at the Geological Society, Burlington House, Piccadilly, London, W.1), at 2.30 p.m.-Mr. G. S. Swecting: "Wouse, Piccadilly, London, W.1), at 2.30 p.m.-Mr.G.

\section{APPOINTMENTS VACANT}

Appuroations are invited for the following appointments on or before the dates mentioned:

HEADS OF THE DEPARTMFNTS OF PHYSIOLOGY, MEDIOINE, AND SURGERY-The Bursar, Royal Veterinary College and Hospital, at The University, Reading (October 1).

FintCATIONAi PSYOHOLOGISI (full-time) to work in the Child Guidance Clinic-The Director of Education, Education Office, 'Iown Hall, Bradford (October 2).

Educational Psychologist (full-time) to be responsible for the direction of the child Guidance Clinic, and A PSYchIATRIst (part-time) -The Director of Education, Education Offices, Woodlands Road, Middlesbrough (October 2).

CHAIR OF NAVAL ARChTTECTURE-The Acting Secretary of University Court, The University, Glasgow (October 4).

HEADMASTER of the Montgomeryshire County Junior Technical School, Newtown-The Director of Education, county Offices, Newtown, Montgomeryshire (October 9).

AGRIOULTURAL EDUCATTON OFFICER-The Executive Officer, War Agricultural Exeoutive Committee, County Offices, Aylesbury, Bucks. (Óctcber 11).

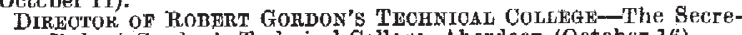
tary, Robert Gordon's Tenhnical College, Aberdeen (Oetober 16). PROFESSOR OF HNGINERRTA-The Registrar, University College, Singleton Park, Swansea (November 20).

SOIENCE Master to teaCh Chemistry and Phrstes at a lcading Boys' School, Jamaica-The British Council, 3 Hanover Street, London, W.1 (endorsed 'Jamaica').

LACTURFR IN NATURAL HISTORY-The Principal, Saffron Walden Trajnitig College, Saffron Walden.

LEOTURER IN NATURE STUDY AND BIOLOGY-The Principal, Dudley Training College, Castle Vicw, Dudlcy.

TOIATITIAN (WOMAN) in the Food Advice Division of the Ministry of Food-The Secretary Central (Technical and Scientific) Register, Ministry of Labour and National Service, Alexandra House, Kingsway, London, W.C.2 (quoting Reference No. ON.F.1425).

condon, W.C.2 (quoting Rerere in the Army Overseas-Ministry of FOOD ANALYSTS for serviee in the Army (Technical and Scientific) Labour and National Register, Alexandra

Dran with considerable experience in workshop DIRECTOR (ENGIN ER with constar operations, Beacher Strect, London, W.1 (endorsed 'Ethiopia').

Strect, London, W.1 (endored on ASSTSTANT MECHANIOAL FNGINEER for mine on Gold Coast engaged on production of essential war material-The Ministry of Labour and National Service, Central ('Technical and Scientific) Register, AlexC.1865X). 